\title{
Implikasi Pandemi Covid-19 Terhadap Pelaksanaan Perjanjian Kredit
}

\author{
Muhammad Akbar Fhad Syahril \\ Sekolah Tinggi IImu Hukum Amsir Parepare \\ Email : akbar9.a9@gmail.com
}

\begin{abstract}
ABSTRAK
This study aims to analyze the impact of the Covid-19 pandemic on debtors who renege on agreements due to Force Majeur as a result of the Covid-19 pandemic. The method was normative-empirical research, with a conceptual approach. The results showed the completion of banking credit agreements as a result of Force Majeure due to the Covid-19 pandemic, which creditors conducted to save debtors from bad loans, including by conducting reduction, reconditioning, and restructuring, the implementation of guarantees through auctions, this is based on Bank Indonesia Regulation.
\end{abstract}

Keywords: Implications, Pandemic Covid-19, Force Majeure, and Credit Agreement

\section{Latar Belakang Masalah}

Pengertian perjanjian, sebagaimana diatur pada Pasal 1313 Kitab Undangundang Hukum Perdata merupakan suatu Perbuatan dengan mana satu orang atau lebih mengikatkan dirinya pada satu orang atau lebih lainnya. ${ }^{1}$ Perjanjian pada umumnya terdiri dari serangkaian janji yang dibuat para pihak dalam sebuah kontrak. Janji sendiri adalah suatu bentuk pernyataan yang dibuat seseorang dan ditujukan kepada orang lain, dimana dalam suatu keadaan atau akan melakukan suatu perbuatan tertentu. Orang terikat pada janjinya sendiri, yakni janji yang diberikan ke pihak lain yang tertuang di dalam perjanjian. Janji itu mengikat dan janji itu menimbulkan utang yang harus ditunaikan.

Perjanjian itu semestinya dibedakan dengan janji. Sekalipun janji itu pada awalnya didasari oleh kata sepakat, namun kata sepakat disini tidak untuk menimbulkan akibat hukum. Sederhananya bahwa, jika janji dilanggar maka tidak ada akibat hukum atau sanksi yang menanti, tapi dengan adanya perjanjian yang dimaksud maka tentulah perbedaan tersebut diakomodasi. Dimana suatu perjanjian kemudian dibarengi dengan perangkat hukum sehingga mengikat para pihak. Verbintenissen disini merupakan suatu hubungan diantara para pihak, sehingga

${ }^{1}$ Ery Agus Priyono, 'Aspek Keadilan Dalam Kontrak Bisnis Di Indonesia (Kajian Pada Perjanjian Waralaba )', Law Reform, 14.1 (2018), 15 <Https://Doi.Org/10.14710/Lr.V14i1.20233>. 
salah satu pihak berhak untuk menuntut suatu hal dari pihak lain, dan pihak tersebut wajib untuk memenuhi tuntutan tersebut. Hubungan antara perikatan dan perjanjian yaitu suatu perjanjian menimbulkan perikatan, dan perjanjian merupakan sumber penting yang melahirkan perikatan, sumber lain tersebur yaitu undang-undang.

Dalam pelaksanaan perjanjian, asas Pacta Sunt Servanda seringkali sulit dilaksanakan bila terjadi perubahan keadaan yang fundamental, keadaan yang menjadi dasar dibuatnya perjanjian telah berubah dan perubahan tersebut mempengaruhi kemampuan pihak-pihak yang berjanji. Tidak jarang perubahan keadaan seperti kenaikan harga, perubahan kurs mata uang dan kondisi perang dapat menyebabkan salah satu atau lebih pihak dalam perjanjian mengalami kerugian apabila perjanjian dilaksanakan. Beberapa sengketa dalam perjanjian diantaranya diakibatkan oleh adanya perubahan keadaan namun Kitab Undangundang Hukum Perdata sebagai ketentuan utama dalam hukum perjanjian belum mengakomodasi hal ini. Dan hal tersebut seringkali dikaitkan dengan keadaan di luar perkiraan (Force Majeure). ${ }^{2}$

Pandemi Covid-19 yang melanda sejak awal tahun ini, sangat berdampak pada surutnya segala bentuk aktivitas-aktivitas ekonomi. Pandemi Covid-19 telah mengganggu kelangsungan yang berdampak pada berbagai macam sektor seperti perbankan, yang berdampak pada debitur dalam hal ketidakmampuan membayar kredit, atau ketidakmampuan berprestasi, disamping itu pandemi Covid-19 juga berdampak pada bidang properti, berdampak pada user dan penyewa dalam hal ketidakmampuan menunaikan kewajibannya dalam berprestasi.

Selain itu pandemi juga berdampak besar pada usaha mikro, kecil, dan menengah dalam hal ketidakmampuan menunaikan kewajiban atas modal. Tidak sampai disitu Covid-19 juga berdampak pada usaha pabrik-pabrik industri, terutama pada pekerja pabrik, pekerja dirumahkan atau pemutusan hubungan kerja meski masa kontrak mereka belum berakhir, hal tersebut juga sangat berpengaruh terhadap perjanjian atau berbagai kontrak bisnis lainnya. Oleh karena terjadinya pendemi Covid-19, maka segala bentuk prestasi mengalami kendala dan keterlambatan karena terdampak Covid-19, keterlambatan pembayaran adalah faktor terjadinya Covid-19 (Force Majeure), sehingga berpengaruh kepada keadaan dan kondisi perekonomian dan kelancaran para pihak yang terdampak pandemi.

\footnotetext{
${ }^{2}$ Lathifah Hanim and Ms. Noorman, 'Penyelesaian Perjanjian Kredit Bank Sebagai Akibatforce Majeure Karena Gempa Di Yogyakarta', Jurnal Pembaharuan Hukum, $3.2 \quad$ (2016), 161 <https://doi.org/10.26532/jph.v3i2.1406>.
} 
Kemudian muncul pertanyaan, apakah pandemi Covid-19 ini bisa menjadi alasan para debitur untuk mengingkari perjanjian dikarenakan keadaan yang mamaksa atau Force Majeur.

\section{Metode Penelitian}

Metode penelitian yang digunakan adalah penelitian hukum normatif-empiris yakni penelitian hukum yang memadukan antara penelitian hukum normatif dan penelitian hukum sosial/empiris. Pada jenis penelitian semacam ini peneliti melakukan penelitian dengan mengkombain kedua tipe penelitian sebagaimana disebutkan diatas dalam sebuah penelitian. ${ }^{3}$ Metode penelitian ini didukung dengan pendekatan konseptual, yaitu jenis pendekatan dalam penelitian hukum yang memberikan sudut pandang analitis tentang pemecahan masalah dalam penelitian hukum, dilihat dari aspek dan konsep hukum di baliknya, juga dapat dilihat dari nilainilai yang terkandung dalam penyemaian suatu aturan yang terkait dengan konsep yang digunakan.

\section{Analisis dan Pembahasan}

Pandemi Covid-19 Menjadi Alasan Mengingkari Perjanjian Karena Force Majeure

Kitab Undang-undang Hukum Perdata memberi pengertian tentang Force Majeure yakni Keadaan debitur terhalang untuk memberikan sesuatu atau melakukan sesuatu atau melakukan perbuatan yang dilarang dalam perjanjian. ${ }^{4}$ Dari pengertian ini yang kemudian disesuaikan dengan terminologi yang digunakan, yaitu keadaan paksa. Keadaan paksa diartikan sebagai suatu kejadian yang terjadi di luar kendali satu pihak.

Pengertian Force Majeure tidak sampai hanya pada perincian peristiwaperistiwa penyebab terjadinya Force Majeure itu sendiri. Lebih lanjut Force Majeure sendiri diartikan sebagai suatu kejadian yang muncul di luar dari kemampuan dan kemauan dari para pihak yang menimbulkan kerugian bagi salah satu pihak. Pengertian yang Force Majeure merupakan keadaan yang terjadi di luar kehendak para pihak, sehingga kewajiban yang tertuang dalam perjanjian menjadi tidak dapat

\footnotetext{
${ }^{3}$ Syahruddin Nawi, Penelitian Hukum Normatif Versus Penelitian Hukum Empiris. 2017.

${ }^{4}$ Kitab Undang-Undang Hukum Perdata (Indonesia).
} 
terpenuhi. ${ }^{5}$ Jadi jelaslah dari kedua pengertian diatas, bahwa keduanya sama-sama mengartikan Force Majeure sebagai keadaan yang terjadi di luar kendali para pihak.

Dalam Pasal 1338 Kitab Undang-undang Hukum Perdata, setiap perjanjian wajib tunduk pada asas itikad baik di dalam pelaksanaannya. Dikarenakan sifat yang mengikat seperti halnya sebuah undang-undang. Namun pengecualian dari ketentuan tersebut tertuang dalam ketentuan yang mengatur mengenai Force Majeure. Yaitu pada Pasal 1244 dan pada Pasal 1245 Kitab Undang-undang Hukum Perdata. Sistem hukum didalam Kitab Undang-undang Hukum Perdata tidak mengintrodusir prinsip dari Rebus Sic Stantibus pada ranah hukum perjanjian, namun lebih kepada mengedepankan aspek Force Majeure.

Ada beberapa teori yang memberikan argumentasi-argumentasi, yakni teori objektif. Teori ini bertitik tolak pada asumsi bahwa, suatu prestasi tidak mungkin bagi setiap orang, yang berarti terkait dengan ketidakmungkinan mutlak bagi setiap orang. Kemudidan teori subjektif, yang pada intinya terkait dengan ketidakmungkinan relatif. ${ }^{6}$

Berdasarkan keputusan Presiden Republik Indonesia Nomor 12 tahun 2020 tentang Penetapan Bencana Nasional Penyebaran Covid-19, sebagai Bencana Nasional maka Covid-19 secara lansung merupakan suatu keadaan memaksa sementara, maka sebagai kondisi sementara karena Wuhan sebagai tempat asal dari wabah Covid-19 sudah dinyatakan aman dari wabah. ${ }^{7}$ Dimulai dari keadaan memaksa relatif, selanjutnya diterbitkan Peraturan Otoritas Jasa Keuangan (POJK) Nomor 11/POJK.03/2020 tentang Stimulus Perekonomian Nasional sebagai Kebijakan Countercyclical. $^{8}$

Dalam Undang-undang Perbankan tidak menjelaskan hubungan hukum pemberian kredit dengan nasabah sebagai peminjam. Salah satu dasar yang cukup jelas bagi bank mengenai keharusan adanya suatu perjanjian kredit adalah ketentuan Pasal 1 angka 11 Undang-undang Perbankan, dimana disebutkan bahwa

\footnotetext{
${ }^{5}$ Lathifah Hanim And Ms. Noorman, 'Penyelesaian Perjanjian Kredit Bank Sebagai Akibatforce Majeure Karena Gempa Di Yogyakarta', Jurnal Pembaharuan Hukum, $3.2 \quad$ (2016), 161 <Https://Doi.Org/10.26532/Jph.V3i2.1406>.

${ }^{6}$ Hanim And Ms. Noorman.

${ }^{7}$ Keputusan Presiden Republik Indonesia Nomor 12 Tahun 2020 Tentang Penetapan Bencana Nonalam Penyebaran Corona Virus Disease 2019 Sebagai Bencana Nasional, Fundamental of Nursing, 2020, p. 18=30.

${ }^{8}$ Peraturan Perturan Otoritas Jasa Keuangan NO.11/POJK.02/2020, Otoritas Jasa Keuangan (OJK), 2020, MMXIX, 2020 <https://www.ojk.go.id/id/regulasi/Documents/Pages/Stimulus-Perekonomian-Nasional-SebagaiKebijakan-Countercyclical-Dampak-Penyebaran-Coronavirus-Disease-2019/Ringkasan Eksekutif POJK 11 2020.pdf>.
} 
kredit diberikan berdasarkan persetujuan atau kesepakatan pinjam-meminjam antara bank dengan pihak lain yang mewajibkan pihak peminjam untuk melunasi utangnya setelah jangka waktu tertentu dengan pemberian bunga. ${ }^{9}$

Maraknya kasus kredit macet perbankan karena bencana alam, seringkali membuat perbankan mengalami dilema. Di satu sisi bank harus memikirkan nasib dirinya agar tetap bertahan dan juga tidak menyalahi regulasi yang berlaku, namun pada sisi lain bank dituntut untuk memberikan rasa kemanusiaannya kepada para nasabah yang mengalami takdir yang tidak diinginkan oleh semua pihak. Lebih lanjut perbankan berdiri dan beroperasi harus selalau mengikuti seperangkat aturan yang telah ditetapkan oleh pihak terkait sebagai bagian dari intetintas resmi dalam sebuah negara. Peristiwa Pandemi Covid-19 ini telah memberikan dampak yang sangat besar dan mengganggu perekonomian Indonesia, bahkan hampir diseluruh daerah yang terkena dampak bencana tersebut diperkirakan akan mengalami kesulitan dalam hal pelaksanaan prestasi terhadap kewajibannya sesuai dengan perjanjian kredit.

Perjanjian yang dibuat para pihak baik itu secara lisan maupun tertulis, tentuya harus mengindahkan asas-asas hukum dalam perjanjian, dan aturan-aturan hukum yang terkait dengan perjanjian. Pemberian kredit pada umumnya dilakukan dengan mengadakan suatu perjanjian. Perjanjian tersebut terdiri dari perjanjian pokok yaitu perjanjian utang piutang dan diikuti dengan perjanjian tambahan berupa perjanjian pemberian jaminan oleh pihak debitur. Setiap kredit yang telah disepakati antara pemberi kredit dan penerima kredit wajib dituangkan dalam bentuk perjanjian yaitu perjanjian kredit. ${ }^{10}$

Hubungan hukum diantara kreditur sebagai peminjam dana dan debitur sebagai penyimpan dana yang kemudian dituangkan dalam bentuk peraturan bank yang bersangkutan, yang berisikan mengenai ketentuan-ketentuan dan syarat-syarat umum yang harus disetujui oleh nasabah untuk penyimpan dana. Hubungan hukum antara pihak bank dan nasabah debitur juga dituangkan ke dalam perjanjian kredit bank. Pada praktiknya perjanjian tersebut berbentuk suatu perjanjian standar atau perjanjian baku. Saat kreditur memberi pinjaman dan debitur selaku penerima pinjaman, maka terjadilah hutang piutang yang kemudian dituangkan dalam

\footnotetext{
${ }^{9}$ Ida Bagus Gde Gni Wastu, I Gusti Ngurah Wairocana, And Desak Putu Dewi Kasih, 'Kekuatan Hukum Perjanjian Kredit Di Bawah Tangan Pada Bank Perkreditan Rakyat', Acta Comitas, 2017, 83 <Https://Doi.Org/10.24843/Ac.2017.V02.I01.P08>.

${ }^{10}$ Munir Fuady, Hukum Perkreditan Kontemporer, 2002.
} 
perjanjian kredit yang bentuknya sudah ditentukan oleh kreditur ke dalam bentuk perjanjian baku.

Perjanjian kredit pada bank merupakan perjanjian awal atau perjanjian pendahuluan dari penyerahan sejumlah uang. Perjanjian pendahuluan adalah hasil hasil permufakatan antara pemberi dan penerima pinjaman baik itu mengenai hubungan-hubungan hukum diantara keduanya. Perjanjian ini bersifat konsensuil, dan penyerahan uangnya sendiri, sifatnya riil. Kemudian pada saat melakukan penyerahan uang, barulah kemudian berlaku ketentuan yang dituangkan ke dalam model suatu perjanjian kredit antara para pihak. Di dalam perjanjian kredit, perjanjian itu dibuat berdasar kesepakatan antara debitur dan kreditur. Ketika terjadi suatu bencana, maka suatu perjanjian kredit kemudian bisa ditinjau ulang berdasar kesepakatan antara para pihak yang terikat dalam perjanjian.

Perjanjian tidak lahir semata-mata karena kesepakatan tapi juga harus memenuhi ketentuan hukum tentang syarat sah perjanjian sebagaimana diatur dalam Pasal 1320 Kitab Undang-undang Hukum Perdata, dengan kata lain perjanjian apapun namanya maupun bentuknya tidak bisa mengabaikan aturan hukum yang berlaku di mana perjanjian itu dibuat dengan semata-mata mengandalkan pada kesepakatan yang didasari pada asas kebebasan berkontrak. ${ }^{11}$

Begitu juga dengan upaya penyelesaian kredit macetpun diserahkan kembali pada kesepakatan di antara debitur dan kreditur, dikarenakan ada beberapa kriteria penggolongan kualitas kredit itu. Selanjutnya untuk menentukan berkualitas tidaknya suatu kredit, maka diberikan ukuran-ukuran tertentu. Bank Indonesia menggolongkan kualitas kredit menurut ketentuan sebagai berikut :

a) Pass adalah kredit yang memenuhi kriteria industri atau kegiatan usaha yang memiliki potensi pertumbuhan yang baik.

b) Special Mention adalah kredit yang memenuhi kriteria industri atau kegiatan usaha memiliki potensi pertumbuhan yang terbatas.

c) Substandard adalah kredit yang memenuhi kriteria industri atau kegiatan usaha menunjukkan potensi pertumbuhan yang sangat terbatas atau tidak mengalami pertunbuhan, perolehan laba rendah.

d) Doubtful adalah kredit yang memenuhi kriteria industri atau kegiatan usaha menurun, laba sangat kecil dan negatif.

11 Ery Agus Priyono, 'Aspek Keadilan Dalam Kontrak Bisnis Di Indonesia (Kajian Pada Perjanjian Waralaba )', Law Reform, 14.1 (2018), 15 <Https://Doi.Org/10.14710/Lr.V14i1.20233>. 
e) Loss adalah kredit yang memenuhi kriteria kelangsungan usaha sangat diragukan, industri mengalami penurunan dan sulit untuk pulih kembali, kemungkinan besar kegiatan usaha akan terhenti. ${ }^{12}$

Penerapan sanksi administratif atau denda dalam administrasi hukum merupakan adaptasi dari aturan hukum pidana. Namun sanksi dalam arti hukum administratif bersifat reparatoris atau kembali ke keadaan semula, bukan menghukum mereka. Sanksi dalam definisi denda dapat diartikan sebagai hukuman yang dilakukan dengan syarat memenuhi asas legalitas. Prinsip legalitas menekankan pada norma atau klausul peraturan. ${ }^{13}$ Pada situasi pandemi seperti saat ini, maka sangatlah dimungkinkan jika debitur mengingkari kontrak yang telah disepakati dengan pihak penyedian layanan dalam artian terbebas dari sanksi administratif atau denda. Peristiwa bencana alam yang melanda seluruh wilayah di Indonesia ini, yang bahkan melanda ke seluruh negara-negara didunia, telah memberikan efek yang berdampak dan sangat mengganggu perekonomian khususnya di Indonesia, terlebih lagi didaerah yang berstatus zona kuning, zona merah dan bahkan berzona hitam.

Nasabah akan mengalami kendala-kendala saat menunaikan kewajibannya sesuai dengan perjanjian kredit. Didalam Kitab Undang-undang Hukum Perdata Pasal 1244, berbunyi debitur harus dihukum untuk mengganti biaya, kerugian dan bunga, bila ia tidak dapat membuktikan bahwa tidak dilaksanakannya perikatan itu atau tidak tepatnya waktu dalam melaksanakan perikatan itu disebabkan oleh sesuatu hal yang tak terduga, yang tak dapat dipertanggungkan kepadanya, walaupun tidak ada itikad buruk kepadanya. ${ }^{14}$ Lebih lanjut pada Pasal 1245 menyatakan bahwa tidak ada penggantian biaya kerugian dan bunga, bila karena keadaan memaksa atau karena hal yang terjadi secara kebetulan, debitur terhalang untuk memberikan atau berbuat sesuatu yang diwajibkan atau melakukan suatu perbuatan yang terlarang baginya. ${ }^{15}$

\footnotetext{
${ }^{12}$ M. Aqim Adlan, 'Penyelesaian Kredit Macet Perbankan Dalam Pandangan Islam Tinjauan Regulasi Kasus Kredit Macet Akibat Bencana Alam', An-Nisbah: Jurnal Ekonomi Syariah, 2.2 (2016) <Https://Doi.Org/10.21274/An.2016.2.2.145-186>.

${ }_{13}$ Alwiyah Sakti Ramdhon Syah Rakia, 'Health Protocol Sanctions Policy in Sorong Mayor Regulation', Amsir Law Journal, 2.2 (2020), 69-78 <https://doi.org/https://doi.org/10.36746/alj.v2i2.38>.

${ }^{14}$ Kitab Undang-Undang Hukum Perdata.

${ }^{15}$ Kitab Undang-Undang Hukum Perdata.
} 
Kesepakatan yang ditempuh oleh para pihak, tentunya mengikat bagi mereka sebagai undang-undang sesuai dengan Pasal 1338 Kitab Undang-undang Hukum Perdata. Penerapan pada asas ini, memberi tempat bagi berlakunya asas konsensual, diamana asas ini mengindikasikan adanya keseimbangan pada posisi tawar, kemudian adanya kesembingan didalam pembagian beban resiko, dan keseimbangan kepentingan.

Dalam setiap pemberian kredit diperlukan adanya pertimbangan serta kehatihatian agar kepercayaan yang merupakan unsur utama dalam kredit benar-benar terwujud sehingga kredit yang diberikan dapat mengenai sasarannya dan terjaminnya pengembalian kredit tepat pada waktunya sesuai perjanjian. ${ }^{16}$

Kredit yang hampir macet maupun yang sudah macet dengan alasan Force Majeur merupakan resiko ditiap pemberian kredit oleh pihak bank. Resiko tersebut bisa berupa keadaan dimana kredit tidak dapat dikembalikan tepat waktu. Kredit yang macet bisa saja disebabkan berbagai faktor seperti adanya kesengajaan dari pihak yang terlibat dalam kredit, ataupun kesalahan prosedur pemberian kredit, dan bahkan disebabkan oleh faktor seperti Pandemi Covid-19.

Dikatakan kredit kategori Non Performing Loan, jika kualitas dari kredit tersebut termasuk pada golongan yang kolektibilitasnya yang kurang lancar, diragukan, atau bahkan macet. Sedangkan untuk Non Performing Loan pada umumnya, bisa diatasi dengan melakukan restrukturisasi, berupa pemberian penurunan bunga kredit, perpanjangan jangka waktu, atau pengurangan tunggakan bunga kredit.

Sehubungan dengan perlindungan terhadap konsumen yang perlu mendapat perhatian utama dalam standar kontrak adalah mengenai klausula eksonerasi yaitu klausula yang berisi pembebasan kewajiban dan pertanggungjawaban pelaku usaha tetapi dibebankan kepada konsumen. ${ }^{17}$ Dalam ketentuan Kitab Undang-undang Hukum Perdata sendiri tidak memuat batasan mengenai keadaan memaksa. Tujuan Overmacht, jika terjadi wanprestasi, maka debitur tidak dinyatakan bersalah. Sehingga cukup jelas bahwa nasabah sebagai debitur pada situasi pandemi tidak bersalah, maka kemudian tidaklah perlu dikenakan sanski administrasi atau ganti rugi, denda, bunga, dan konsekuensi lainnya.

\footnotetext{
${ }^{16}$ Sutarno, Aspek-Aspek Hukum Perkreditan Pada Bank, 2003.

${ }^{17}$ Sri Lestari Poernomo, 'Standar Kontrak Dalam Perspektif Hukum Perlindungan Konsumen', Jurnal Penelitian Hukum De Jure, 19.1 (2019), 109 <https://doi.org/10.30641/dejure.2019.v19.109-120>.
} 
Dalam hal ini, perlunya diperhatikan juga mengenai unsur Overmacht berdasar pada Pasal 1244 sampai dengan Pasal 1245, yakni :

a) Sesuatu hal yang tak terduga (Unexpected Event)

b) Keadaan memaksa (Insistence)

c) Secara kebetulan (Coincidentally)

d) Para pihak tidak dapat dipertanggungkan (Parties Cannot Be Accounted)

e) Kejadian harus di luar kendali para pihak (Non Contributory Effect)

f) Adanya itikad baik (Good Faith, Goed Voornemen)

Jika unsur-unsur itu terpenuhi, maka barulah para pihak dikatakan bisa terhindar dari dugaan wanprestasi, karena tidak melaksanakan prestasi atau break the agreement. Sedangkan jika mengacu pada hukum acara, maka Pandemi Covid19 sudah merupakan Notoir Feit yang diketahui bersama dan tidak terbantahkan, sehingga tidak perlu untuk dibuktikan lagi. Jika ditelaah secara teoritis Force Majeure (Overmacht) terbagi menjadi dua, yakni :

a) Absolute Overmacht keadaan yang sifatnya tetap sehingga pelaksanaan prestasi tidak mungkin dilakukanpara pihak terikat kontrak.

b) Relative Overmacht sifat keadaan memaksa sementara sehingga pemenuhan prestasi masih mungkin dilakukan

Jika faktor keadaan memaksa sudah tidak ada lagi, maka kewajiban untuk berprestasi muncul kembali. Secara langsung atau tidak, akan berdampak pada kinerja dan kapasitas para pihak, sehingga mempengaruhi kemampuan para pihak dalam memenuhi kesepakatan yang tertuang dalam kontrak. Seperti debitur misalnya, akan mengalami kesulitan dan kendala didalam memenuhi kewajiban membayar atau mengangsur utang.

Pandemi merupakan Force Majeure (Overmacht), yang masuk kategori keadaan darurat, dimana keadaan memaksa yang ditimbulkan oleh situasi atau kondisi yang tidak wajar, keadaan khusus yang bersifat segera, dan berlangsung singkat, tanpa bisa diprediksi jauh sebelumnya. Dalam keadaan memaksa ini, terjadi peristiwa yang tidak terduga yang terjadi di luar kesalahan para debitur setelah terjadinya sebuah perjanjian, sehingga peristiwa tersebut menghalangi debitur untuk memenuhi prestasinya sebelum dinyatakan lalai, dan oleh karenanya debitur tidak dapat disalahkan untuk tidak menanggung risiko atas peristiwa tersebut. 
Dampak dari penyebaran Covid-19 ini telah sangat memadai untuk bisa digunakan oleh para pihak yang terikat kontrak menunda kewajiban. Untuk menunda kewajiban, berpedoman pada Surat Edaran Bank Indonesia Nomor 26/4/BPPP tanggal 29 mei 1993. Edaran tersebut pada prinsipnya mengatur tetang penyelamatan kredit yang bermasalah, sebelum dilakukan penyelesaian lewat lembaga hukum atau melalui badan alternatif lainnya.

Berdasarakan pada Peraturan Otoritas Jasa Keuangan, terdapat sedikitnya tiga hal, yang dapat dilakukan untuk menunda kewajiban dalam hal ini penyelamatan kredit, diantaranya yakni:

a) Rescheduling, merupakan upaya pertama dari pihak bank untuk menyelamatkan kredit yang diberikannya kepada debitur. Cara ini dilakukan jika ternyata pihak debitur tidak mampu untuk memenuhi kewajibannya dalam hal pembayaran kembali angsuran pokok maupun bunga kredit.

b) Reconditioning, dengan melakukan perubahan baik sebagian atau menyeluruh dari persyaratan perjanjian dengan tidak memberikan tambahan kredit dan tanpa melakukan konversi penyertaan. Perubahan kondisi kredit dibuat dengan memperhatikan masalah-masalah yang dihadapi oleh debitur dalam pelaksanaan proyek atau bisnisnya

c) Restrukturisasi, dengan melakukan perubahan terhadap syarat-syarat berupa pemberian tambahan kredit misalnya atau dengan melakukan konversi terhadap penyertaan tanpa Rescheduling dan Reconditioning.

Dengan diterbitkannya kebijakan berupa kesempatan yang diberikan kepada debitur selaku nasabah untuk mengatur kembali kewajibannya yang kemudian disesuaikan dengan kondisi perekonomian. Dari kebijakan yang sama juga diberlakukan bagi perusahaan nonbank dan nasabahnya, kebijakan pemberian kemudahan bukan hanya beraku spesifik di Indonesia saja, tetapi kebijakan serupa juga dilakukan negara yang terkena dampak pandemi Covid-19.

\section{Kesimpulan}

Penyelesaian perjanjian kredit bank sebagai akibat Force Majeure karena pandemi Covid-19, yang dilakukan kreditur untuk menyelamatkan debitur dari kredit macet tersebut yakni dengan melakukan Recheduling, Reconditioning, dan Restructuring, kemudian eksekusi jaminan melalui lelang. Hal ini berdasar pada 
Peraturan Bank Indonesia Nomor 8/10/PBI/2006 Peraturan Bank Indonesia Nomor 8/15/PBI/2006, dan Peraturan Bank Indonesia Nomor 11/27/PBI/2009.

\section{Referensi}

Adlan, M. Aqim, 'Penyelesaian Kredit Macet Perbankan Dalam Pandangan Islam Tinjauan Regulasi Kasus Kredit Macet Akibat Bencana Alam', AnNisbah: Jurnal Ekonomi Syariah, $2.2 \quad$ (2016) $<$ Https://Doi.Org/10.21274/An.2016.2.2.145-186>

Alwiyah Sakti Ramdhon Syah Rakia, 'Health Protocol Sanctions Policy In Sorong Mayor Regulation', Amsir Law Journal, 2.2 (2020), 69-78 $<$ Https://Doi.Org/Https://Doi.Org/10.36746/Alj.V2i2.38>

Fuady, Munir, Hukum Perkreditan Kontemporer, 2002

Gni Wastu, Ida Bagus Gde, I Gusti Ngurah Wairocana, And Desak Putu Dewi Kasih, 'Kekuatan Hukum Perjanjian Kredit Di Bawah Tangan Pada Bank Perkreditan Rakyat', Acta Comitas, 2017, 83 <Https://Doi.Org/10.24843/Ac.2017.V02.101.P08>

Hanim, Lathifah, And Ms. Noorman, 'Penyelesaian Perjanjian Kredit Bank Sebagai Akibat Force Majeure Karena Gempa Di Yogyakarta', Jurnal $\begin{array}{llll}\text { Pembaharuan Hukum, } & 3.2 & \text { (2016), } & 161\end{array}$ <Https://Doi.Org/10.26532/Jph.V3i2.1406>

Keputusan Presiden Republik Indonesia Nomor 12 Tahun 2020 Tentang Penetapan Bencana Nonalam Penyebaran Corona Virus Disease 2019 Sebagai Bencana Nasional, Fundamental Of Nursing, 2020, P. 18=30

Kitab Undang-Undang Hukum Perdata (Indonesia)

Nawi, Syahruddin, Penelitian Hukum Normatif Versus Penelitian Hukum Empiris, 5Th (Makassar: Pt.Umitoha Ukhuwah Grafika, 2017)

Peraturan Perturan Otoritas Jasa Keuangan No.11/Pojk.02/2020, Otoritas Jasa Keuangan (OJK), 2020, MMXIX, 2020 <Https://Www.Ojk.Go.Id/Id/Regulasi/Documents/Pages/StimulusPerekonomian-Nasional-Sebagai-Kebijakan-Countercyclical-DampakPenyebaran-Coronavirus-Disease-2019/Ringkasan Eksekutif Pojk 11 2020.Pdf>

Poernomo, Sri Lestari, 'Standar Kontrak Dalam Perspektif Hukum Perlindungan Konsumen', Jurnal Penelitian Hukum De Jure, 19.1 (2019), 109 <Https://Doi.Org/10.30641/Dejure.2019.V19.109-120>

Priyono, Ery Agus, 'Aspek Keadilan Dalam Kontrak Bisnis Di Indonesia (Kajian Pada Perjanjian Waralaba)', Law Reform, 14.1 (2018), 15 <Https://Doi.Org/10.14710/Lr.V14i1.20233>

Sutarno, Aspek-Aspek Hukum Perkreditan Pada Bank, 2003 